\title{
Development of a Coal Quality Expert
}

\author{
U.S. Department of Energy \\ Pittsburgh Energy Technology Center \\ Pittsburgh, Pennsylvania
}

DE-FC22-90PC89663

October 5, 1994

\author{
DISCLAIMER
}

This report was prepared as an account of work sponsored by an agency of the United States Government. Neither the United States Government nor any agency thereof, nor any of their employees, makes any warranty, express or implied, or assumes any legal liability or responsibility for the accuracy, completeness, or usefulness of any information, apparatus, product, or process disclosed, or represents that its use would not infringe privately owned rights. Reference herein to any specific commercial product, process, or service by trade name, trademark, manufacturer, or otherwise does not necessarily constitute or imply its endorsement, recommendation, or favoring by the United States Government or any agency thereof. The views and opinions of authors expressed herein do not necessarily state or reflect those of the United States Government or any agency thereof.

CQ Inc.

One Quality Center

Post Office Box 280

Homer City, Pennsylvania 15748

(412) $479-3503$ 


\section{DISCLAIMER}

Portions of this document may be illegible in electronic image products. Images are produced from the best available original document. 
November 16, 1994

Mr. James Watts

U.S. Department of Energy

Pittsburgh Energy Technology Center

Post Office Box 10940

Pittsburgh, Pennsylvania 15236

RE: Development of a Coal Quality Expert

DOE Contract No. DE-FC22-90PC89663

Technical Progress Report No. 17 (Final)

Dear Jim:

Please find enclosed two final copies of the $17^{\text {th }}$ Technical Progress Report, describing work performed under the above contract for the second quarter of 1994.

A draft of the $18^{\text {th }}$ Technical Progress Report, covering the third quarter of 1994 , is in preparation and will be submitted shortly for your review.

Sincerely,<smiles>CC(C)(C)NC1CCCC1</smiles>

Clark D. Harrison

Project Manager

$\mathrm{CDH} /$ gas

enc.

xc: Dave O’Connor (EPRI)

Dick Borio (ABB/CE)

Dan Giovanni (EPT)

Scott Stallard (B\&V)

Glenn Shirey (CQ)

Jurgen Brat (CQ)
James Huemmrich (DOE)

Dr. C. Lowell Miller (DOE)

Paul Gottlieb (DOE)

Kent Hancock (DOE)

Dr. S.N. Roger Rao (Burns \& Roe) DOE Office of Technology Transfer 
This is the seventeenth Technical Progress Report, describing work performed under DOE Contract No. DE-FC22-90PC89663, "Development of a Coal Quality Expert." The contract is a Cooperative Agreement between the U.S. Department of Energy, CQ Inc., and ABB Combustion Engineering, Inc. This report covers the period from April I through June 30, 1994. Five companies and five host utilities have teamed with $C Q$ Inc. and $A B B / C E$ to perform the work on this project. The work falls under DOE's Clean Coal Technology Program category of "Advanced Coal Cleaning." The 51-month project will provide the utility industry with a PC software program to confidently and inexpensively evaluate the potential for coal cleaning, blending, and switching options to reduce emissions while producing lowest cost electricity. Specifically, this project will:

- Enhance the existing Coal Quality Information System (CQIS) database and Coal Quality Impact Model (CQIM) to allow confident assessment of the effects of cleaning on specific boiler cost and performance.

- Develop and validate a methodology, Coal Quality Expert (CQE), which allows accurate and detailed predictions of coal quality impacts on total power plant capital cost, operating cost, and performance based upon inputs from inexpensive bench-scale tests.

The project consists of the following seven tasks:

- Task 1 - Project Management

- Task 2 - Coal Cleanability Characterization

- $\quad$ Task 3 - Pilot-Scale Combustion Testing

- Task 4 - Utility Boiler Field Testing

- Task 5 - CQIM Completion and Development of CQE Specification

- Task 6 - Develop CQE

- Task 7 - CQE Workstation Testing and Validation 
WORK PERFORMED

Task 6 - Develop CQE
Project emphasis during the past quarter was directed toward technical model and software development under Task 6. A project working meeting was held in June to review the status of various software development activities and finalize the project work scope for completing the CQE software.

Work continued on the development of the Model Constructor, which will be used to create and edit equipment system information graphically. A new style of graphical elements to represent the different types of equipment and the connections between them was developed.

A conceptual design for the look of the Interactive Output Utility (IOU) was created in a Freelance presentation format. This tool provides the software developer with the capability to layout the design for multiple screens in a short period of time, while also allowing others to interact with a particular design before coding.

New versions of the ONTOS database system (in dynamic link library form) and Borland $\mathrm{C}++$ for $\mathrm{OS} / 2$ (Version 1.5) were obtained.

A project working meeting was held June 23 at Black and Veatch's offices in Kansas City to finalize a work scope and schedule for completing the CQE software within the constraints of available project funding. Representatives from DOE, EPRI, CQ Inc., and B\&V participated. The results from that meeting are summarized below.

Development of the CQE software will continue under the guidance of the CQE Specification. Although the completed product will not contain all functionality identified in the specification, it will contain the core functionality needed to bring the software to market and provide a foundation for future enhancements. The PC-based program will be capable of evaluating various qualities of coal, available transportation options, performance issues, and alternative emissions control strategies for utility power stations. The $\mathrm{CQE}$ will be composed of technical tools to evaluate performance issues; environmental models to evaluate emission and regulatory issues; and cost estimating models to predict costs for installations of new and retrofit coal 
cleaning processes, power production equipment, and emissions control systems as well as other productions costs such as consumables (fuel, scrubber additive, etc.), waste disposal, operating and maintenance, and replacement energy costs. These technical, environmental, and economic models as well as a graphical user interface will be developed for the CQE.

Completion of $\mathrm{CQE} 1.0$ will entail the following tasks:

- Complete CQE User Interface, employing graphical screen elements such as windows, menus, and dialog boxes.

- Develop a Model Constructor to assist the user in building and editing plant, unit, and equipment system models.

- Design and implement Interactive Output Utilities (IOUs) and reports for presenting CQE output.

- Complete four key applications: Fuel Evaluator, Plant Engineer, Environmental Planner, and the Coal Cleaning Expert.

- Finalize fuel transportation capabilities of $\mathrm{CQE}$ and requirements for importing CQIM/CQIS coal data and CCSEM data into CQE format.

- Complete CQE Help Facilities and user security systems.

- Improve functional and technical capabilities, incorporating the following models: $\mathrm{NO}_{\mathrm{x}}$ prediction model, boiler model (including interface with SLAGGO and FOULER models), electrostatic precipitator model, and a pulverizer model (roll-andrace and ball mills).

- Integrate ONTOS database management system for information/data storage and management.

- Develop default configuration, cost, and performance functions. 
- Prepare CQE program documentation, including a Program Usage Manual and a document summarizing the basic theory of the CQE Program.

The features of CQE 1.0 are summarized in Figure 1, including a listing of incorporated models and potential future enhancements. In addition, CQLM C ++ code developed under another EPRI project will be contributed to the project and utilized for coal handling, air heater, fans, bottom ash, fly ash and waste disposal systems and the M/A, derate, sensitivity, and economic analyses. 


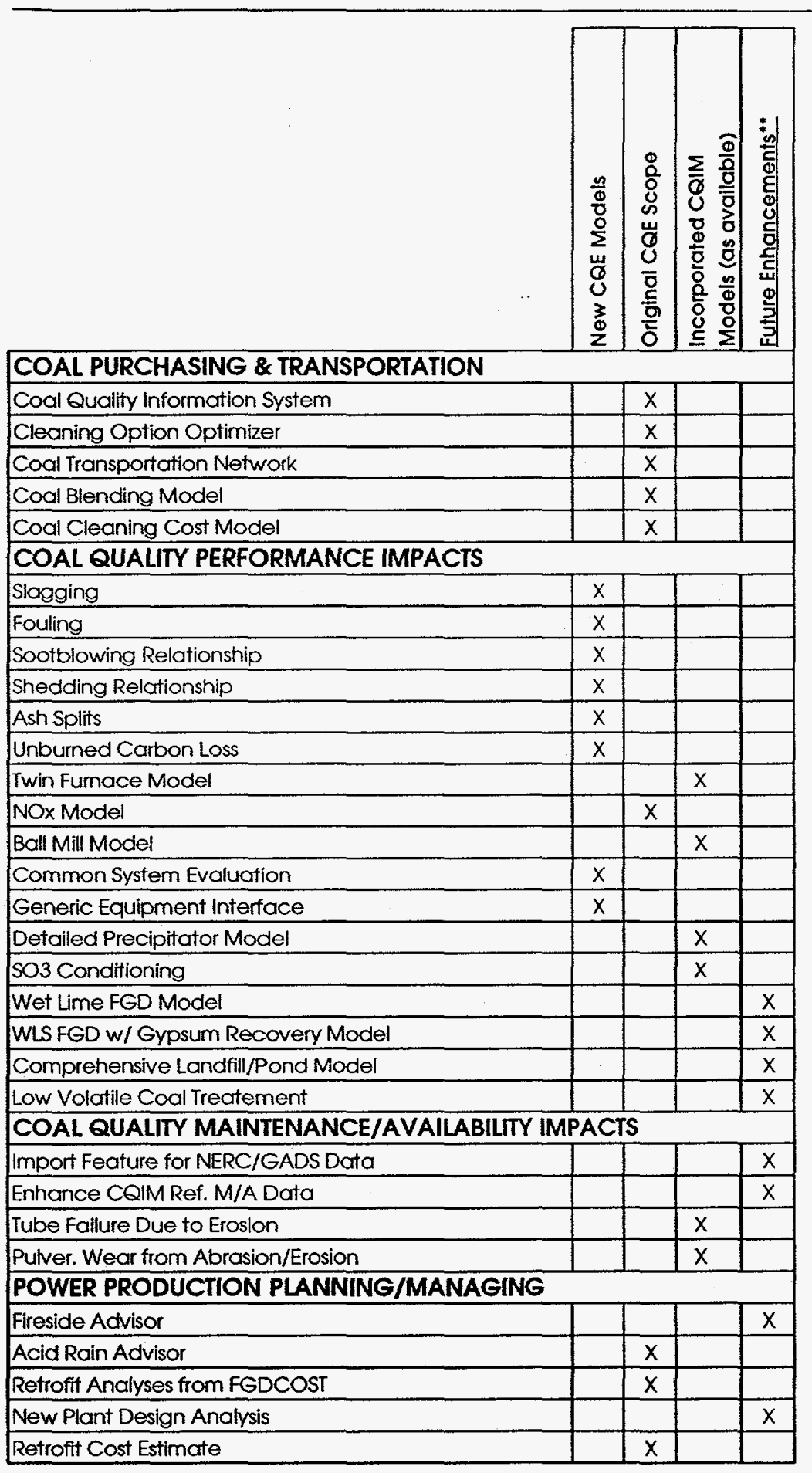

** Future enhancements for succeeding software versions.

Figure 1. CQE 1.0 Models 